\title{
Synthesis of some novel triazole derivatives as anti-nociceptive and anti-inflammatory agents
}

AIYALU RAJASEKARAN ${ }^{1 *}$

KALASALINGAM ANANDA RAJAGOPAL ${ }^{2}$

${ }^{1} \mathrm{KMCH}$ College of Pharmacy

Coimbatore, Tamilnadu, India

${ }^{2}$ AK College of Pharmacy

Krishnankoil, Tamilnadu, India
Eight novel 1-[2-(1H-tetrazol-5-yl)ethyl]- $1 H$-benzo[ $d][1,2$, 3] triazoles (3a-h) have been synthesized in order to obtain new compounds with potential anti-nociceptive and anti-inflammatory activity. The titled compounds were synthesized by the condensation of 1-[2-( $1 H$-tetrazol-5-yl) ethyl]- $1 H$-benzotriazole (2) and appropriate acid chlorides. Compound 2 was synthesized by reacting 3-(1H-benzo[ $d][1,2,3]$ triazol-1-yl)propanonitrile (1) with sodium azide and ammonium chloride in the presence of dimethylformamide. The synthesized compounds were characterized by spectroscopic methods (IR, ${ }^{1} \mathrm{H}$ NMR, mass spectroscopy) and elemental analysis. The titled compounds were evaluated for anti-nociceptive activity by the hot plate method and the writhing response method, and anti-inflammatory activity was evaluated by the carragenean induced paw edema method. 5-(2-(1H-benzo[ $d][1,2,3]$ triazo-1-yl)ethyl)-1 $H$-tetrazol-1-yl)(4-aminophenyl)methanone (3d) and 5-(2-(1H-benzo[d][1,2,3]triazo-1-yl)ethyl)-1H-tetrazol-1-yl)(2-hydroxyphenyl)methanone (3g) exhibited significant anti-nociceptive activity. 1-(2-(1-Tosyl$-1 H$-tetrazol-5-yl)ethyl)-1H-benzo[ $d][1,2,3]$ triazole $(3 \mathrm{c})$ and 4,5-(2-(1H-benzo[ $d][1,2,3]$ triazo-1-yl)ethyl)- $1 H$-tetrazol-1-yl sulfonyl)benzenamine (3f) elicited superior anti-inflammatory activity compared to other synthesized compounds. Further investigations are needed to discern the mechanism of action.

Keywords: synthesis, 1-[2-(1H-tetrazol-5-yl)ethyl]-1H-benzo[ $d][1,2,3]$ triazoles, anti-nociception, anti-inflammation

Tetrazole is a five-membered ring structure composed of four nitrogen atoms and one carbon atom and is used as an intermediate in the synthesis of pharmaceuticals, especially cephalosporins. Tetrazole and its derivatives have been reported to possess anti-nociceptive (1), anti-inflammatory (2), antimicrobial (3) and anticonvulsant properties $(4,5)$. Benzotriazole moiety is a versatile lead molecule in pharmaceutical development

\footnotetext{
* Correspondence; e-mail: rsekaran2001in@yahoo.co.in
} 
A. Rajasekaran and K. A. Rajagopal: Synthesis of some novel triazole derivatives as anti-nociceptive and anti-inflammatory agents, Acta Pharm. 59 (2009) 355-364.

and has a wide range of biological activities, e.g., anti-inflammatory (6), anti-nociceptive (7), anticonvulsant (8), antimicrobial (9), protein kinase inhibiting (10) and immunosuppressive activities (11). Our research was focused on incorporation of the benzotriazole moiety into tetrazoles based upon the hypothesis that this modification would improve efficacy, since both moieties are noted for their anti-nociceptive and anti-inflammatory properties. Thus, a series of novel 1-[2-(1H-tetrazol-5-yl)ethyl]- $1 H$-benzo[ $d][1,2,3]$ triazoles were synthesized and tested for their anti-nociceptive and anti-inflammatory properties.

\section{EXPERIMENTAL}

Melting points were determined using a melting point apparatus (Veego, VMP III, India) and were not corrected. Infrared spectra were obtained on a Perkin Elmer FTIR spectrophotometer 1600 series (Perkin Elmer, USA) using potassium bromide discs. ${ }^{1} \mathrm{H}$ NMR spectra were recorded on a Bruker $400 \mathrm{MHz}$ spectrophotometer (Bruker, USA). Chemical shifts are reported in parts per million $(\delta)$ units relative to an internal standard

Table I. Physical and analytical data of synthesized compounds

\begin{tabular}{|c|c|c|c|c|c|c|c|}
\hline \multirow{2}{*}{ Compd. } & \multirow{2}{*}{ Mol. formula } & \multirow{2}{*}{ Mol. mass ${ }^{\mathrm{a}}$} & \multirow{2}{*}{$\begin{array}{l}\text { M.p. } \\
\left({ }^{\circ} \mathrm{C}\right)\end{array}$} & \multirow{2}{*}{$\begin{array}{c}\text { Yield } \\
(\%)\end{array}$} & \multicolumn{3}{|c|}{ Elemental analysis (calcd./found, \%) } \\
\hline & & & & & $\mathrm{C}$ & $\mathrm{H}$ & $\mathrm{N}$ \\
\hline \multirow{2}{*}{1} & \multirow{2}{*}{$\mathrm{C}_{9} \mathrm{H}_{8} \mathrm{~N}_{4}$} & \multirow{2}{*}{172.19} & \multirow{2}{*}{$89-92$} & \multirow{2}{*}{73} & 62.87 & 4.68 & 32.54 \\
\hline & & & & & 62.62 & 4.64 & 32.42 \\
\hline \multirow{2}{*}{2} & \multirow{2}{*}{$\mathrm{C}_{9} \mathrm{H}_{9} \mathrm{~N}_{7}$} & \multirow{2}{*}{215.22} & \multirow{2}{*}{$68-72$} & \multirow{2}{*}{78} & 50.23 & 4.22 & 45.56 \\
\hline & & & & & 50.39 & 4.14 & 43.52 \\
\hline \multirow{2}{*}{$3 a$} & \multirow{2}{*}{$\mathrm{C}_{16} \mathrm{H}_{13} \mathrm{~N}_{7} \mathrm{O}$} & \multirow{2}{*}{319.33} & \multirow{2}{*}{$95-102$} & \multirow{2}{*}{76} & 60.18 & 4.10 & 30.70 \\
\hline & & & & & 60.34 & 4.42 & 30.68 \\
\hline \multirow{2}{*}{$3 b$} & \multirow{2}{*}{$\mathrm{C}_{16} \mathrm{H}_{12} \mathrm{~N}_{8} \mathrm{O}_{3}$} & \multirow{2}{*}{364.32} & \multirow{2}{*}{$80-85$} & \multirow{2}{*}{76} & 52.75 & 3.32 & 30.76 \\
\hline & & & & & 52.64 & 3.42 & 30.58 \\
\hline \multirow{2}{*}{$3 c$} & \multirow{2}{*}{$\mathrm{C}_{16} \mathrm{H}_{15} \mathrm{~N}_{7} \mathrm{O}_{2} \mathrm{~S}}$. & \multirow{2}{*}{369.41} & \multirow{2}{*}{ 180-182 } & \multirow{2}{*}{73} & 52.02 & 4.09 & 26.54 \\
\hline & & & & & 52.34 & 4.14 & 26.78 \\
\hline \multirow{2}{*}{$3 d$} & \multirow{2}{*}{$\mathrm{C}_{16} \mathrm{H}_{14} \mathrm{~N}_{8} \mathrm{O}$} & \multirow{2}{*}{334.34} & $220-226$ & 75 & 57.48 & 4.22 & 33.52 \\
\hline & & & $\angle \angle O-\angle \angle 6$ & 15 & 57.34 & 4.33 & 33.68 \\
\hline $3 e$ & $\mathrm{C}_{16} \mathrm{H}_{14} \mathrm{~N}_{8} \mathrm{O}$ & 334.34 & $140-146$ & 64 & 57.48 & 4.22 & 33.52 \\
\hline & & 334.34 & $140-146$ & 64 & 57.34 & 4.14 & 33.21 \\
\hline $3 f$ & $\mathrm{C}_{15} \mathrm{H}_{14} \mathrm{~N}_{8} \mathrm{O}_{2} \mathrm{~S}$ & 370.39 & $242-245$ & 72 & 48.64 & 3.81 & 30.25 \\
\hline & & & $242-245$ & $1 / 2$ & 48.49 & 3.62 & 30.43 \\
\hline $3 g$ & $\mathrm{C}_{16} \mathrm{H}_{13} \mathrm{~N}_{7} \mathrm{O}_{2}$ & 335,32 & $167-170$ & 67 & 57.31 & 3.91 & 29.24 \\
\hline & $16^{+113^{2}}+0_{2}$ & & $16 /-1 / 0$ & $6 \gamma$ & 57.34 & 4.05 & 29.28 \\
\hline $3 \mathrm{~h}$ & $\mathrm{C}_{16} \mathrm{H}_{13} \mathrm{~N}_{7} \mathrm{O}_{2}$ & 335,32 & $234-237$ & 66 & 57.31 & 3.91 & 29.24 \\
\hline & 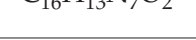 & & & & 57.44 & 4.08 & 29.38 \\
\hline
\end{tabular}

\footnotetext{
a Molecular mass determination by mass spectral analysis $(\mathrm{M}+)$
} 
A. Rajasekaran and K. A. Rajagopal: Synthesis of some novel triazole derivatives as anti-nociceptive and anti-inflammatory agents, Acta Pharm. 59 (2009) 355-364.

of tetramethylsilane. Mass spectra were recorded on a mass spectrometer (Jeol JMS-DX 303 (Jeol, Japan) and Finnigan MAT 8230 (Finnigan MAT, Germany). Elemental analyses were performed on a Heraeus Carlo Erba 1108 (Elementar, USA) and the analyses were within $\pm 0.4 \%$ of theoretical values.

\section{Synthesis of 3-(1H-Benzo[d][1,2,3]triazol-1-yl)propanonitrile (1)}

Benzotriazole $(50 \mathrm{mmol})$ was mixed with acrylonitrile $(12.5 \mathrm{~mL})$ and cooled in an ice bath. A resorcinol crystal was added to prevent polymerization. Triton B ( $2 \mathrm{~mL}, 40 \%$ $V / V)$ was added dropwise under shaking and a vigorous reaction was observed. It was allowed to subside and was then refluxed on a steam bath for $2 \mathrm{~h}$. The solution was cooled, extracted with ethylene dichloride and dried over anhydrous sodium sulphate. The dried nitrile was recrystallized from ether. The desired 3-(1H-benzo[ $d][1,2,3]$ triazol-1-yl)propanonitrile (1) was obtained as a solid.

Table II. Spectral data of synthesized compounds

\begin{tabular}{|c|c|c|}
\hline Compd. & IR $(\mathrm{KBr})\left(\mathrm{cm}^{-1}\right)$ & ${ }^{1} \mathrm{H}$ NMR $\left(\mathrm{DMSO}-d_{6}\right)(\delta, \mathrm{ppm})$ \\
\hline 1 & $2958(\mathrm{C}-\mathrm{H}), 2254(\mathrm{C} \equiv \mathrm{N}), 1456(\mathrm{C}-\mathrm{H})$ & $\begin{array}{c}2.7\left(2 \mathrm{H}, \mathrm{t}, J=7.1 \mathrm{~Hz}, \mathrm{CH}_{2}\right), 4.4(2 \mathrm{H}, \mathrm{t}, \\
\left.J=7.1 \mathrm{~Hz}, \mathrm{CH}_{2}\right), 6.8-7.3(8 \mathrm{H}, \mathrm{m}, \mathrm{Ar}-\mathrm{H}) .\end{array}$ \\
\hline 2 & $\begin{array}{c}3462(\mathrm{~N}-\mathrm{H}), 2926(\mathrm{C}-\mathrm{H}), 2853(\mathrm{C}-\mathrm{H}) \\
1639(\mathrm{C}=\mathrm{N}), 1458(\mathrm{C}-\mathrm{H}), 1286 \\
(\mathrm{~N}-\mathrm{N}=\mathrm{N}-), 1197 \text { (tetrazole ring) }\end{array}$ & $\begin{array}{l}2.8\left(2 \mathrm{H}, \mathrm{t}, J=7.1 \mathrm{~Hz}, \mathrm{CH}_{2}\right), 4.3(2 \mathrm{H}, \mathrm{t} \\
\left.J=7.1 \mathrm{~Hz}, \mathrm{CH}_{2}\right), 6.8-7.3(8 \mathrm{H}, \mathrm{m}, \mathrm{Ar}-\mathrm{H}) .\end{array}$ \\
\hline $3 a$ & $\begin{array}{c}2930(\mathrm{C}-\mathrm{H}), 1695(\mathrm{C}=\mathrm{O}), 1437(\mathrm{C}-\mathrm{H}) \\
1282(\mathrm{~N}-\mathrm{N}=\mathrm{N}-), 1108 \text { and } 1138 \\
\text { (tetrazole ring) }\end{array}$ & $\begin{array}{l}2.8\left(2 \mathrm{H}, \mathrm{t}, J=7.1 \mathrm{~Hz}, \mathrm{CH}_{2}\right), 4.3(2 \mathrm{H}, \mathrm{t} \\
\left.J=7.1 \mathrm{~Hz}, \mathrm{CH}_{2}\right), 6.8-7.3(9 \mathrm{H}, \mathrm{m}, \mathrm{Ar}-\mathrm{H})\end{array}$ \\
\hline $3 b$ & $\begin{array}{c}2887(\mathrm{C}-\mathrm{H}), 1774(\mathrm{C}=\mathrm{O}), 1576\left(\mathrm{NO}_{2}\right) \\
1457 \& 1367(\mathrm{C}-\mathrm{H}), 1283(\mathrm{~N}-\mathrm{N}=\mathrm{N}-) \\
1110 \text { (tetrazole ring) }\end{array}$ & $\begin{array}{l}2.8\left(2 \mathrm{H}, \mathrm{t}, J=7.1 \mathrm{~Hz}, \mathrm{CH}_{2}\right), 4.3(2 \mathrm{H}, \mathrm{t} \\
\left.J=7.1 \mathrm{~Hz}, \mathrm{CH}_{2}\right), 6.8-8.1(8 \mathrm{H}, \mathrm{m}, \mathrm{Ar}-\mathrm{H})\end{array}$ \\
\hline $3 c$ & $\begin{array}{c}2930(\mathrm{C}-\mathrm{H}), 1774(\mathrm{C}=\mathrm{O}), 1618(\mathrm{C}=\mathrm{N}) \\
1457(\mathrm{C}-\mathrm{H}), 1283(\mathrm{~N}-\mathrm{N}=\mathrm{N}-), 1108,1133 \\
\text { (tetrazole ring), } 1044\left(\mathrm{SO}_{2}\right)\end{array}$ & $\begin{array}{c}\delta 2.1\left(3 \mathrm{H}, \mathrm{s}, \mathrm{CH}_{3}\right), 2.8(2 \mathrm{H}, \mathrm{t}, J=7.1 \mathrm{~Hz} \\
\left.\mathrm{CH}_{2}\right), 4.3\left(2 \mathrm{H}, \mathrm{t}, J=7.1 \mathrm{~Hz}, \mathrm{CH}_{2}\right), 6.8-7.7 \\
(8 \mathrm{H}, \mathrm{m}, \mathrm{Ar}-\mathrm{H})\end{array}$ \\
\hline $3 d$ & $\begin{array}{c}3464(\mathrm{~N}-\mathrm{H}), 2798(\mathrm{C}-\mathrm{H}), 1666(\mathrm{C}=\mathrm{O}) \\
1457(\mathrm{C}-\mathrm{H}), 1301(\mathrm{~N}-\mathrm{N}=\mathrm{N}-), 1105 \\
\text { and } 1162 \text { (tetrazole ring) }\end{array}$ & $\begin{array}{c}2.8\left(2 \mathrm{H}, \mathrm{t}, J=7.1 \mathrm{~Hz}, \mathrm{CH}_{2}\right), 4.3 \\
\left(2 \mathrm{H}, \mathrm{t}, J=7.1 \mathrm{~Hz}, \mathrm{CH}_{2}\right), 4.5\left(2 \mathrm{H}, \mathrm{s}, \mathrm{NH}_{2}\right) \\
6.8-7.3(8 \mathrm{H}, \mathrm{m}, \mathrm{Ar}-\mathrm{H})\end{array}$ \\
\hline $3 \mathbf{e}$ & $\begin{array}{c}3463(\mathrm{~N}-\mathrm{H}), 2798(\mathrm{C}-\mathrm{H}), 1666(\mathrm{C}=\mathrm{O}) \\
1486(\mathrm{C}-\mathrm{H}), 1301(\mathrm{~N}-\mathrm{N}=\mathrm{N}-), 1105 \\
\text { and } 1162(\text { tetrazole ring) }\end{array}$ & $\begin{array}{c}2.8\left(2 \mathrm{H}, \mathrm{t}, J=7.1 \mathrm{~Hz}, \mathrm{CH}_{2}\right), 4.3(2 \mathrm{H}, \mathrm{t} \\
\begin{array}{c}\left.J=7.1 \mathrm{~Hz}, \mathrm{CH}_{2}\right), 4.5\left(2 \mathrm{H}, \mathrm{s}, \mathrm{NH}_{2}\right), 6.8-7.7 \\
(8 \mathrm{H}, \mathrm{m}, \mathrm{Ar}-\mathrm{H})\end{array}\end{array}$ \\
\hline $3 f$ & $\begin{array}{c}3383(\mathrm{~N}-\mathrm{H}), 1434(\mathrm{CH}), 1282(\mathrm{~N}-\mathrm{N}=\mathrm{N}), \\
1132 \text { (tetrazole ring), } 1031(\mathrm{SO} 2)\end{array}$ & $\begin{array}{c}2.8\left(2 \mathrm{H}, \mathrm{t}, J=7.1 \mathrm{~Hz}, \mathrm{CH}_{2}\right), 4.3(2 \mathrm{H}, \mathrm{t} \\
\left.J=7.1 \mathrm{~Hz}, \mathrm{CH}_{2}\right), 4.5\left(2 \mathrm{H}, \mathrm{s}, \mathrm{NH}_{2}\right), 6.8-7.3 \\
(8 \mathrm{H}, \mathrm{m}, \mathrm{Ar}-\mathrm{H})\end{array}$ \\
\hline $3 g$ & $\begin{array}{c}3372(\mathrm{O}-\mathrm{H}), 1774(\mathrm{C}=\mathrm{O}), 1457(\mathrm{C}-\mathrm{H}) \\
1295(\mathrm{~N}-\mathrm{N}=\mathrm{N}-), 1138 \text { (tetrazole ring }\end{array}$ & $\begin{array}{c}2.1\left(3 \mathrm{H}, \mathrm{s}, \mathrm{CH}_{3}\right), 2.8\left(2 \mathrm{H}, \mathrm{t}, J=7.1 \mathrm{~Hz}, \mathrm{CH}_{2}\right) \\
4.3\left(2 \mathrm{H}, \mathrm{t}, J=7.1 \mathrm{~Hz}, \mathrm{CH}_{2}\right), 5(1 \mathrm{H}, \mathrm{s}, \mathrm{OH}) \\
6.8-7.6(8 \mathrm{H}, \mathrm{m}, \mathrm{Ar}-\mathrm{H})\end{array}$ \\
\hline $3 h$ & $\begin{array}{c}3371(\mathrm{O}-\mathrm{H}), 1744(\mathrm{C}=\mathrm{O}), 1458(\mathrm{C}-\mathrm{H}) \\
1283(\mathrm{~N}-\mathrm{N}=\mathrm{N}-), 1108 \text { and } 1138 \\
\text { (tetrazole ring) }\end{array}$ & $\begin{array}{c}2.1\left(3 \mathrm{H}, \mathrm{s}, \mathrm{CH}_{3}\right), 2.8\left(2 \mathrm{H}, \mathrm{t}, J=7.1 \mathrm{~Hz}, \mathrm{CH}_{2}\right), \\
4.3\left(2 \mathrm{H}, \mathrm{t}, J=7.1 \mathrm{~Hz}, \mathrm{CH}_{2}\right), 5(1 \mathrm{H}, \mathrm{s}, \mathrm{OH}) \\
6.8-7.9(8 \mathrm{H}, \mathrm{m}, \mathrm{Ar}-\mathrm{H})\end{array}$ \\
\hline
\end{tabular}




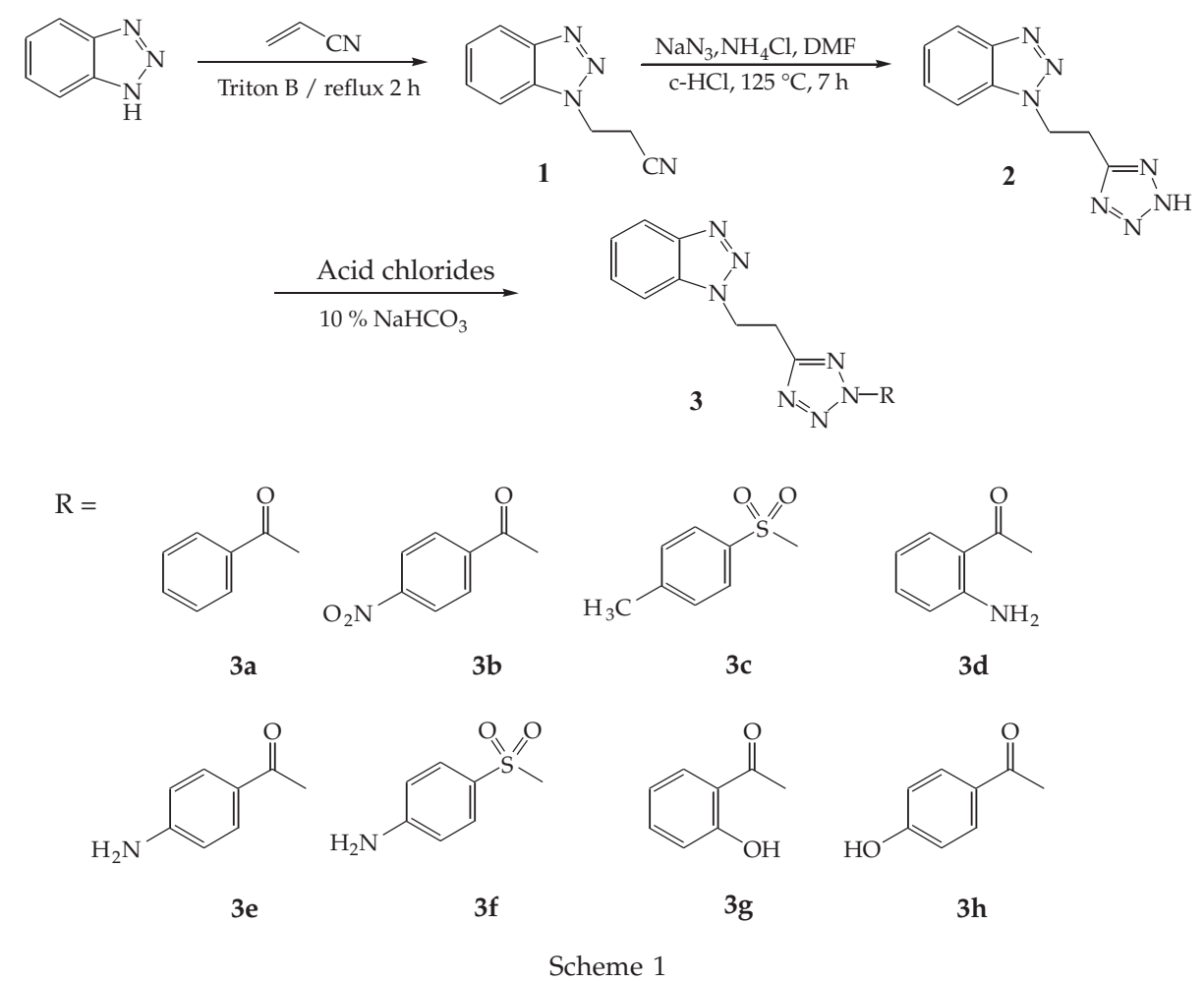

\section{Synthesis of 1-[2-(1H-tetrazol-5-yl)-ethyl]-1H-benzotriazole (2)}

Equimolar quantities of compound (1), sodium azide, dimethylformamide (10 mL) and ammonium chloride were heated in an oil bath for $7 \mathrm{~h}$ at $125^{\circ} \mathrm{C}$. The solvent was removed under reduced pressure, the residue was dissolved in $100 \mathrm{~mL}$ of water and carefully acidified with concentrated hydrochloric acid to $\mathrm{pH} 2$. The solution was cooled to $5{ }^{\circ} \mathrm{C}$ in an ice bath. Compound 2 was recrystallized from aqueous methanol.

\section{Synthesis of 1-[2-(1H-tetrazol-5-yl)ethyl]-1H-benzo[d][1,2,3]triazoles $(3 a-h)$.} General procedure

Compound 2 was treated with an equimolar amount of aromatic acid chlorides in $10 \mathrm{~mL}$ of sodium bicarbonate solution $(10 \% \mathrm{~m} / \mathrm{V})$. The mixture was shaken vigorously until the odor of aromatic acid chloride disappeared. The solids which separated out were filtered and dried. Recrystallization of the dried compounds from aqueous ethanol yielded compounds $3 \mathbf{a}-\mathbf{h}$. 
A. Rajasekaran and K. A. Rajagopal: Synthesis of some novel triazole derivatives as anti-nociceptive and anti-inflammatory agents, Acta Pharm. 59 (2009) 355-364.

\section{Pharmacological screening}

Acute toxicity study. - This involves estimation of the median lethal dose $\left(L D_{50}\right)(12)$, which is the dose that will kill $50 \%$ of the animal population within $24 \mathrm{~h}$ post treatment with the test substance. All animal experiments were conducted under the conditions of the Animal Scientific Procedures. The experimental protocol was approved by the Animal Care Review Committee of the AK College of Pharmacy, India. Groups of Swiss albino mice consisted of six animals and were maintained in colony cages at $25 \pm 2{ }^{\circ} \mathrm{C}$, relative humidity of $45-55 \%$, under a $12 \mathrm{~h}$ light and dark cycle; they were fed standard animal feed and water ad libitum. They were treated intraperitoneally with different doses of test compounds $\left(200,400,600,800,1000 \mathrm{mg} \mathrm{kg}^{-1}\right)$. The animals were then observed for $24 \mathrm{~h}$ for any behavioral effects such as nervousness, excitement, dullness, in-coordination or even death. The $L D_{50}$ was found to be $180 \mathrm{mg} \mathrm{kg}^{-1}$.

Hot plate method. - All the newly synthesized compounds were tested for anti-nociceptive activity by the Eddy and Leimbach method (13). Swiss albino mice were divided into ten groups of six mice each. One group served as control and was administered $0.5 \%$ $(V / V)$ Tween $80(0.5 \mathrm{~mL})$ suspension. One group was administered the standard drug pentazocine (Sigma, USA) intraperitoneally at a dose of $5 \mathrm{mg} \mathrm{kg}^{-1} 15$ minutes before the analgesic activity evaluation. Tween 80 suspension $(0.5 \%, V / V)$ of test compounds 3a-h was administered intraperitoneally at a dose at $18 \mathrm{mg} \mathrm{kg}^{-1}$ to the remaining groups 15 minutes before the analgesic activity evaluation. The reaction time in seconds was noted for all the groups on Eddy's hot plates before and 15 minutes after administration of test compounds and pentazocine (Table III).

Table III. Evaluation of anti-nociceptive activity by the hot plate method

\begin{tabular}{ccc}
\hline & \multicolumn{2}{c}{ Reaction time (s) } \\
\cline { 2 - 3 } Compd. (dose) & before treatment $^{\mathrm{a}}$ & after 15 minutes $^{\mathrm{a}}$ \\
\hline 3a $\left(18 \mathrm{mg} \mathrm{kg}^{-1}\right)$ & $3.75 \pm 0.55$ & $8.66 \pm 0.37^{\mathrm{b}}$ \\
3b $\left(18 \mathrm{mg} \mathrm{kg}^{-1}\right)$ & $3.66 \pm 0.66$ & $73 \pm 0.42^{\mathrm{c}}$ \\
3c $\left(18 \mathrm{mg} \mathrm{kg}^{-1}\right)$ & $4.24 \pm 0.89$ & $12.33 \pm 0.55^{\mathrm{b}}$ \\
3d $\left(18 \mathrm{mg} \mathrm{kg}^{-1}\right)$ & $3.88 \pm 0.56$ & $13.00 \pm 0.34^{\mathrm{b}}$ \\
3e $\left(18 \mathrm{mg} \mathrm{kg}^{-1}\right)$ & $4.52 \pm 0.76$ & $9.50 \pm 0.43^{\mathrm{b}}$ \\
3f $\left(18 \mathrm{mg} \mathrm{kg}^{-1}\right)$ & $3.98 \pm 0.24$ & $10.68 \pm 0.88^{\mathrm{b}}$ \\
3g $\left(18 \mathrm{mg} \mathrm{kg}^{-1}\right)$ & $2.98 \pm 0.35$ & $13.83 \pm 0.34^{\mathrm{b}}$ \\
3h $\left(18 \mathrm{mg} \mathrm{kg}^{-1}\right)$ & $4.12 \pm 0.55$ & $11.50 \pm 0.42^{\mathrm{b}}$ \\
Control & $3.32 \pm 0.46$ & $3.33 \pm 0.55$ \\
Pentazocine $\left(5 \mathrm{mg} \mathrm{kg}^{-1}\right)$ & $4.68 \pm 0.29$ & $13.34 \pm 0.46^{\mathrm{b}}$ \\
\hline
\end{tabular}

Control - no synthesized compound and paracetamol.

a Mean $\pm \operatorname{SEM}(n=6)$.

Significant difference compared with the control: ${ }^{\mathrm{b}} p<0.001,{ }^{\mathrm{c}} p<0.01$. 
Acetic acid induced writhing method. - The synthesized compounds were also tested for anti-nociceptive activity by the acetic acid induced writhing method (14). The animals were divided into ten groups of six. The control group of animals was administered $0.5 \%(V / V)$ Tween $80(0.5 \mathrm{~mL})$ suspension. The standard drug paracetamol (Micro Labs, India) was administered intraperitoneally at a dose of $2.5 \mathrm{mg} \mathrm{kg}^{-1}$. Tween 80 suspension $(0.5 \%, V / V)$ of test compounds were administered intraperitoneally at a dose of $18 \mathrm{mg} \mathrm{kg}^{-1}$. Twenty minutes after administration of the test compounds and a standard, all groups of mice were given the writhing agent, $3 \%(V / V)$ aqueous acetic acid at a dose of $2 \mathrm{~mL} \mathrm{~kg}^{-1}$ intraperitoneally. The total number of writhings produced in these animals was counted visually for 15 minutes and the number of writhings produced in treated groups was compared with that in the control group. The results given in Table IV are expressed as percentage protection.

Anti-inflammatory activity. - The anti-inflammatory activity was evaluated by the carragenean induced paw edema method (15). Albino rats of Wistar strain, weighing 100-200 g, of either sex were divided into ten groups of six animals each. The animals were maintained under normal environmental conditions. They were fed standard feed and water ad libitum. Tween 80 suspension $(0.5 \%, V / V)$ of test compounds was administered intraperitoneally at a dose of $18 \mathrm{mg} \mathrm{kg}^{-1}$. The control group was given only $0.5 \%$ $(V / V)$ Tween $80(0.5 \mathrm{~mL})$ suspension. One group was administered diclofenac sodium as standard, intraperitoneally at a dose of $2 \mathrm{mg} \mathrm{kg}^{-1}$. Thirty minutes after the administration of test compounds and diclofenac sodium, paw edema was induced in albino rats by injecting $0.1 \mathrm{~mL}$ of carragenean suspension $(1 \%, V / V$ in normal saline), into subplantar region of the left hind paw of each rat. Tree hours after carragenean injection, the increase in paw volume was measured with a plethysmometer. The anti-inflammatory activity was measured in terms of percentage inhibition of edema and analyzed (Table V).

Table IV. Anti-nociceptive activity by the acetic acid-induced writhing method

\begin{tabular}{ccc}
\hline Compd. (dose) & $\begin{array}{c}\text { No. of writhings } \\
\text { (after } 15 \text { minutes) }^{\mathrm{a}}\end{array}$ & Protection (\%) \\
\hline 3a $\left(18 \mathrm{mg} \mathrm{kg}^{-1}\right)$ & $28 \pm 1^{\mathrm{b}}$ & 58 \\
3b $\left(18 \mathrm{mg} \mathrm{kg}^{-1}\right)$ & $34 \pm 1$ & 37 \\
3c $\left(18 \mathrm{mg} \mathrm{kg}^{-1}\right)$ & $23 \pm 0^{\mathrm{b}}$ & 62 \\
3d $\left(18 \mathrm{mg} \mathrm{kg}^{-1}\right)$ & $16 \pm 1^{\mathrm{b}}$ & 70 \\
3e $\left(18 \mathrm{mg} \mathrm{kg}^{-1}\right)$ & $19 \pm 1^{\mathrm{b}}$ & 67 \\
3f $\left(18 \mathrm{mg} \mathrm{kg}^{-1}\right)$ & $21 \pm 1^{\mathrm{b}}$ & 63 \\
3g $\left(18 \mathrm{mg} \mathrm{kg}^{-1}\right)$ & $9 \pm 1^{\mathrm{b}}$ & 85 \\
$3 \mathrm{~h}\left(18 \mathrm{mg} \mathrm{kg}^{-1}\right)$ & $14 \pm 1^{\mathrm{b}}$ & 72 \\
Control & $54 \pm 1$ & - \\
Paracetamol $\left(2.5 \mathrm{mg} \mathrm{kg}^{-1}\right)$ & $9 \pm 1^{\mathrm{b}}$ & 88 \\
\hline
\end{tabular}

Control - no synthesized compound and diclofenac sodium.

a Mean \pm SEM $(n=6)$.

Significant difference compared with the control: ${ }^{\mathrm{b}} p<0.001,{ }^{\mathrm{c}} p<0.01$. 
A. Rajasekaran and K. A. Rajagopal: Synthesis of some novel triazole derivatives as anti-nociceptive and anti-inflammatory agents, Acta Pharm. 59 (2009) 355-364.

Table V. Anti-inflammatory activity of synthesized compounds by the carragenean-induced paw edema method

\begin{tabular}{ccc}
\hline Compd. (dose) & Paw volume (in $\mathrm{mL})^{\mathrm{a}}$ & Inhibition after 3 h (\%) \\
\hline 3a $\left(18 \mu \mathrm{g} \mathrm{kg}^{-1}\right)$ & $0.38 \pm 0.02$ & 14 \\
3b $\left(18 \mu \mathrm{g} \mathrm{kg}^{-1}\right)$ & $0.39 \pm 0.03$ & 11 \\
3c $\left(18 \mu \mathrm{g} \mathrm{kg}^{-1}\right)$ & $0.24 \pm 0.04$ & $45^{\mathrm{b}}$ \\
3d $\left(18 \mu \mathrm{g} \mathrm{kg}^{-1}\right)$ & $0.36 \pm 0.03$ & 18 \\
3e $\left(18 \mu \mathrm{g} \mathrm{kg}^{-1}\right)$ & $0.38 \pm 0.02$ & 14 \\
3f $\left(18 \mu \mathrm{g} \mathrm{kg}^{-1}\right)$ & $0.23 \pm 0.03$ & $47^{\mathrm{b}}$ \\
3g $\left(18 \mu \mathrm{g} \mathrm{kg}^{-1}\right)$ & $0.30 \pm 0.22$ & 32 \\
3h $\left(18 \mu \mathrm{g} \mathrm{kg}^{-1}\right)$ & $0.31 \pm 0.32$ & 30 \\
Control & $0.44 \pm 0.19$ & - \\
Diclofenac sodium $(2 \mu \mathrm{g} \mathrm{kg}$ & & $61^{\mathrm{b}}$ \\
\hline
\end{tabular}

Control - no synthesized compound and diclofenac sodium.

a Mean $\pm \operatorname{SEM}(n=6)$.

Significant difference compared with the control: ${ }^{\mathrm{b}} p<0.01$.

\section{Statistical analysis}

Statistical analysis of the biological activity of synthesized compounds on animals was evaluated using a one-way analysis of variance (ANOVA). In all cases, posthoc comparisons of the means of individual groups were performed using Tukey's test. All values were expressed as mean \pm SEM. The GraphPad Prism 3.0 version was used for statistical analysis.

\section{RESULTS AND DISCUSSION}

The key intermediate 3-(1H-benzo[ $d][1,2,3]$ triazol-1-yl)propanonitrile (1) was prepared by refluxing $1 H$-benzo[ $d][1,2,3]$ triazole with acrylonitrile and Triton B. IR spectra of compound 1 showed intense peaks at $2254 \mathrm{~cm}^{-1}$ and confirmed the formation of nitrile (CN). Two triplets at $\delta 2.7$ and $4.4 \mathrm{ppm}$ of ${ }^{1} \mathrm{H}$ NMR spectrum confirmed the presence of two methylene protons and a multiplet between $\delta 6.8$ and $7.3 \mathrm{ppm}$ confirmed the presence of aromatic protons $(8 \mathrm{H})$ in compound 1 . Further, the molecular ion recorded $(m / z 172$ $[\mathrm{M}+])$ in the mass spectrum is also in agreement with the molecular mass of the compound.

1-[2-(1H-tetrazol-5-yl)ethyl]- $1 H$-benzotriazole (2) was synthesized by reacting 3-(1H-benzo[d][1,2,3]triazol-1-yl)propanonitrile (1) with sodium azide and ammonium chloride in the presence of dimethylformamide. The IR spectrum of compound 2 showed disappearance of $\mathrm{CN}$ stretching signals of nitrile. It showed a peak for the tetrazole ring at $1197 \mathrm{~cm}^{-1},-\mathrm{N}-\mathrm{N}=\mathrm{N}-$ stretching at $1286 \mathrm{~cm}^{-1}$ and $\mathrm{NH}$ stretching at $3462 \mathrm{~cm}^{-1}$. The ${ }^{1} \mathrm{H}$ NMR spectrum of compound 2 showed two triplets for methylene protons and a 
A. Rajasekaran and K. A. Rajagopal: Synthesis of some novel triazole derivatives as anti-nociceptive and anti-inflammatory agents, Acta Pharm. 59 (2009) 355-364.

multiplet at $\delta 6.8-7.3 \mathrm{ppm}$ for aromatic $(8 \mathrm{H})$ protons. Molecular ion recorded in the mass spectrum $(m / z 215[\mathrm{M}+])$ confirmed the assigned structure.

1-[2-(1H-tetrazol-5-yl)ethyl]-1H-benzotriazole (2) has a free secondary amino group which can readily react with acid chlorides. Hence, the titled compounds, 1-[2-(1H-tetrazol-5-yl)ethyl]- $1 H$-benzo[ $d][1,2,3]$ triazoles $(3 \mathbf{a}-\mathbf{h})$, were obtained by substitution of various aromatic carbonyl and sulphoxide moieties using aromatic acid chlorides in the presence of sodium bicarbonate solution. Formation of the titled compounds was confirmed by the disappearance of the peak due to $\mathrm{NH}$ stretching of compound 2 . IR spectra of all compounds 3a-h showed the presence of peaks due to $(\mathrm{N}-\mathrm{N}=\mathrm{N})$ and the tetrazole ring. ${ }^{1} \mathrm{H}$ NMR spectra of all compounds 3a-h showed absorption signals at $\delta 2.8$ and $4.3 \mathrm{ppm}$ for the two methylene protons and multiplet signals between 6.8 and $7.8 \mathrm{ppm}$ for the presence of aromatic protons. Mass spectra of the titled compounds showed molecular ion peaks corresponding to their molecular formula. Elemental analysis satisfactorily confirmed the elemental composition and purity of the synthesized compounds.

The results of analgesic testing indicated that the test compounds $\mathbf{3 d}$ and $\mathbf{3 g}$ exhibited significant analgesic activity after $15 \mathrm{~min}$ of reaction time (13 and 13.83), tested by the hot plate method. Substitution of the amino group in $\mathbf{3 d}$ and hydroxyl group in $\mathbf{3 g}$ in ortho position of aryl moiety increased the anti-nociceptive activity. All other compounds exhibited moderate anti-nociceptive activity. With the exception of $\mathbf{3 b}$, all the compounds exhibited anti-nociceptive activity tested by the acetic acid induced writhing method at a dose of $18 \mathrm{mg} \mathrm{kg}^{-1}$. The anti-nociceptive activity of compounds $\mathbf{3 d}, \mathbf{3 e}$, $3 \mathrm{~g}$ and $3 \mathrm{~h}$ was found to be superior compared to other synthesized compounds. Compounds $3 \mathrm{~d}$ and $3 \mathrm{~g}$ were found to be the most active derivatives tested by both the hot plate method and the acetic acid induced writhing method; they possess 2-aminobenzoyl and 2-hydroxybenzoyl group at the tetrazole moiety of the benztriazole framework.

Synthesized compounds 3a-h exhibited poor anti-inflammatory activity (16-22 \% protection only) against carragenean induced paw edema, whereas the standard drug diclofenac sodium (Novartis Laboratories, India) showed $61 \%$ inhibition under similar conditions. Among the compounds tested, compounds $3 \mathrm{c}$ and $3 \mathrm{f}$ exhibited mild anti-inflammatory activity. Inclusion of substituted benzoyl moiety in the tetrazole moiety of benzotriazole framework did not produce any marked inhibition of edema. However, inclusion of substituted sulfonyl moiety in $\mathbf{3 f}$ resulted in mild anti-inflammatory properties.

\section{CONCLUSIONS}

In the present study, synthesis of a new series of 1-[2-(1H-tetrazol-5-yl)ethyl]- $1 H$ -benzo[ $d][1,2,3]$ triazoles (3a-h) has been described. Compounds $\mathbf{3 d}$ and $\mathbf{3 g}$ were found to be the most active derivatives with promising anti-nociceptive activity. We can deduce from the results that replacement of active hydrogen from the tetrazole moiety with substituted benzoyl and sulfonyl moiety can create potent anti-nociceptive compounds, whereas replacement of active hydrogen from the tetrazole moiety with substituted sulfonyl moiety may lead to mild anti-inflammatory activity. Further studies on structural modifications are needed to increase the anti-inflammatory activity. 
A. Rajasekaran and K. A. Rajagopal: Synthesis of some novel triazole derivatives as anti-nociceptive and anti-inflammatory agents, Acta Pharm. 59 (2009) 355-364.

\section{REFERENCES}

1. A. Rajasekaran and P. P. Thampi, Synthesis and anti-nociceptive activity of some substituted-\{5-[2-1,2,3,4-tetrahydrocarbazol-9-yl)ethyl]tetrazol-1-yl\}alkanones, Eur. J. Med. Chem. 40 (2005) 1359-1364; DOI: 10.1002/chin.200617137.

2. A. Rajasekaran and P. P. Thampi, Synthesis and anti-inflammatory activity of some 10-[(1-acyl-1H-tetrazol-5-yl)ethyl]-10h-phenothiazines, Acta Pharm. Turc. 45 (2003) 235-240.

3. A. O. De Souza, M. T. Pedrosa, J. B. Alderete, A. F. Cruz, M. A. Prado, R. B. Alves and C. L. Silva, Cytotoxicity, antitumoral and antimycobacterial activity of tetrazole and oxadiazole derivatives, Pharmazie 60 (2005) 396-397.

4. A. Rajasekaran and P. P. Thampi, Synthesis and analgesic evaluation of some 5-[beta-(10-phenothiazinyl)ethyl]-1-(acyl)-1,2,3,4-tetrazoles, Eur. J. Med. Chem. 39 (2004) 273-279; DOI: 10.1002/ chin.200433179.

5. A. Rajasekaran, S. Murugesan and K. Anandarajagopal, Antibacterial, antifungal and anticonvulsant evaluation of newly synthesized 1-1-[2-(1H-tetrazol-5-yl)ethyl]-1H-benzo[d][1,2,3]triazoles, Arch. Pharm. Res. 29 (2006) 535-540.

6. U. S. Göksen, N. G. Kelekçi, O. Göktas, Y. Köysal, E. Kiliç, S. Isik, G. Aktay and M. Ozalp, 1-Acylthiosemicarbazides, 1,2,4-triazole-5(4H)-thiones, 1,3,4-thiadiazoles and hydrazones containing 5-methyl-2-benzoxazolinones: synthesis, analgesic-anti-inflammatory and antimicrobial activities, Bioorg. Med. Chem. 15 (2007) 5738-5751; DOI: 10.1086/586711.

7. R. M. Claramunt, D. S. María, E. Pinilla, M. R. Torres and J. Elguero, Structural studies of two Tinuvin P analogs: 2-(2,4-dimethylphenyl)-2H-benzotriazole and 2-phenyl-2H-benzotriazole, Molecules 21 (2007) 2201-2214; DOI: 10.3390/12092201.

8. A. Rajasekaran, V. Rajamanickam, P. T. Kumaresan, S. Murugesan and V. Sivakumar, Analgesic and anti-epileptic activity of N-Mannich bases of some substituted benztriazole, Int. J. Chem. Sci. 2 (2004) 445-449.

9. T. Yoshikawa, Y. Mine, K. Morikage and N. Yoshida, Pharmacological profile of AS-9705, a novel benzotriazole carboxamide derivative, as a gastroprokinetic agent with potent anti-emetic activity, Arzneimittelforsch. 53 (2003) 98-106; DOI: 10.1088/0953-8984.

10. A. B. Najda, M. Lebska M, A. Orzeszko, K. Kopañska, E. Krzywiñska, G. Muszyñska and M. Bretner, Synthesis of new analogs of benzotriazole, benzimidazole and phthalimide potential inhibitors of human protein kinase CK2, Bioorg. Med. Chem. 15 (2009) 1573-1578; DOI: 10.1016/ j.bmc.2008.12.071.

$S A \check{Z} E T A K$

\section{Sinteza novih derivata triazola kao anti-nociceptivnih i protuuaplnih agenasa}

AIYALU RAJASEKARAN i KALASALINGAM ANANDA RAJAGOPAL

Sintetizirano je osam novih 1-[2-(1H-tetrazol-5-il)etil]-1H-benzo[d][1,2,3]triazola (3a-h) s potencijalnim anti-nociceptivnim i protuupalnim djelovanjem. Navedeni spojevi pripravljeni su kondenzacijom 1-[2-(1H-tetrazol-5-il)etil]-1H-benzotriazola (2) i odgovarajućih kiselinskih klorida. Spoj 2 dobiven je reakcijom 3-(1H-benzo[d][1,2,3]triazol-1-il)propanonitrila (1) s natrijevim azidom i amonijevim kloridom u prisutnosti dimetilformamida. Sintetizirani spojevi su karakterizirani spektroskopskim metodama (IR, ${ }^{1} \mathrm{H}$ NMR, spek- 
A. Rajasekaran and K. A. Rajagopal: Synthesis of some novel triazole derivatives as anti-nociceptive and anti-inflammatory agents, Acta Pharm. 59 (2009) 355-364.

troskopijom masa) i elementarnom analizom. Anti-nociceptivno djelovanje ispitivano je metodom vruće ploče i praćenjem odgovora na bolne podražaje, dok je protuupalno djelovanje evaluirano testom s karageninom. 5-(2-(1H-benzo[ $d][1,2,3]$ triazo-1-il)etil)- $1 H$-tetrazol-1-il)(4-aminofenil)metanon (3d) i 5-(2-(1H-benzo[d][1,2,3]triazo-1-il)etil)- $1 H$-tetrazol-1-il) (2-hidroksifenil)metanon (3g) pokazali su značajno anti-nociceptivno djelovanje. 1-(2-(1-Tosil-1H-tetrazol-5-il)etil)-1H-benzo[d][1,2,3]triazol (3c) i 4-5-(2-(1H-benzo[d][1,2, 3]triazo-1-il)etil)-1H-tetrazol-1-il sulfonil)benzenamin (3f) pokazali su superiorno protuupalno djelovanje u odnosu na druge sintetizirane spojeve. Daljnja istraživanja su nužna kako bi se razjasnio mehanizam djelovanja.

Ključne riječi: sinteza, 1-[2-(1H-tetrazol-5-il)etil]-1H-benzo[d][1,2,3]triazol, nocicepcija, upala KMCH College of Pharmacy, Coimbatore, Tamilnadu, India

AK College of Pharmacy, Krishnankoil, Tamilnadu, India 